\title{
Addiction and Trauma Re-examined through the lens of Complexity Theory
}

\author{
Fabio Beni* and Daniele Santoni \\ Researcher, Italy
}

Submission: August 08, 2019; Published: August 29, 2019

*Corresponding author: Researcher, Loc. La Fonte 10, Incisa Valdarno (Fi), 50064, Italy

\begin{abstract}
Upon reviewing the scientific research in the fields of pathological addiction and trauma, we find that there is a broad overlap between the neurophysiological substrate of memory and learning mechanisms in subjects suffering from these two ailments. We observe how these patients may develop an extraordinary ability to use their addiction, or their post-traumatic personality, in a generative way, by polarizing their functioning more and more intensely and pervasively around the substance or the post-traumatic transformation, which ends up functioning as an attractor, as defined in Complexity Theory. Such a process then sometimes also brings these patients to a 'titanic' type of functioning, which - again according to Complexity Theory - may be described as a hypercycle. We further observe that such dissociation from every other part of the personality is like the phenomenon described by Ferenczi [1] with the concept of Orpha, which takes place after a trauma allowing the traumatized person to go on living while experiencing a deep dissociative process.
\end{abstract}

Keywords: Complexity Theory; Hypercycle; Attractor; Substance-Induced Dissociation; Drug Addiction; Trauma

\section{Introduction}

In our practice as psychotherapists we have worked with a great number of cases of pathological addiction and trauma, in both private and public ${ }^{1}$ healthcare environments. Since 2004 we have met with almost a thousand patients a year who suffered from some form of addiction and/or trauma, providing them with initial consulting sessions and personality assessments, as well as continuing sessions and treatment based on psychotherapy and often psychoanalysis as well.

In previous works [2,3], we defined substance-induced dissociation as referring to a dissociative phenomenon boosted - though not generated - by the use and abuse of psychotropic substances and the addictive behaviours linked to them. In the same way, certain abnormal post-traumatic personalities are also boosted by dissociative phenomena that lead traumatized people to have both adaptive and pathological abilities, even years after the traumatic event.

In this paper, we start by reviewing the literature on the neurophysiology of these two fields of severe psychopathology and highlight the inherent similarities. We then re-examine the fields of pathological addiction and trauma through the lens of two key concepts of Complexity Theory, highlighting the dissociative process present in both, and point out how the application of the concepts of attractor and hypercycle $[4,5]$ provides a coherent interpretative framework as well as a useful clinical tool.

\section{Neurophysiological Observations in Cases of Trauma and Addiction}

Many literature studies have shown how the effects of trauma $[6,7]$ and severe drug-addiction $[8,12]$ can capture the mind of the affected individual making it gravitate entirely around the traumatic memory and the substance abuse, respectively to the complete detriment of any other memory or everyday activity. For this reason, any external stimulus not directly connected to trauma or addiction has minimum impact on these individuals, with drastic consequences on their learning and mnemonic processes. The ability and motivation to learn new functional strategies, as well as new life skills, is impaired, as is the capacity to control oneself and not give-in to impulsive behaviors $[13,14]$.

${ }^{1}$ In Italy there are dedicated public health departments for addiction, in which the authors have worked together. 
It is also widely known that severely traumatized individuals have distorted access to their memories, in that these subjects' minds are over-conditioned to go directly to the memory of the trauma. In fact, it has been observed that the recollection of the traumatic memory produces an increase in physiological activity [15]. The subject's mind remembers the trauma on top of everything else, in a constant sort of hypermnesia, but side by side with a form of amnesia, which completely deletes all other non-traumatic memories and, as Janet noted for the first time [16], this clearly interferes with common everyday life activities. Essentially, the memory of the traumatic experience becomes the top priority in the mind of the traumatized individual conditioning his/her behaviour accordingly.

Besides the distortion of the mnestic process, alterations in the learning process are also characteristic in trauma victims. Exposure to "inescapable" traumatic events has long-term effects on the individual, such as incapacity to avoid new traumatic situations [17] and lack of motivation to learn new strategies of avoidance [18]. Paradoxically, each traumatic experience increases the risk of traumatic relapses.

It is interesting to note how many of the characteristics of trauma victims are shared by drug addicts as well:

i. Chronic drug abuse increases Protein-Kinase-A (PKA) ${ }^{2}$ activity, in the dopamine regulatory function, in the corticolimbic-striatal circuit [19], which, in turn, activates the $\mathrm{CREB}^{3}$ [20]. Alterations of PKA and CREB levels in the amygdala or in the nucleus accumbens can heighten the ability to exercise the conditioned reinforcement of the stimuli linked to substance abuse, until these stimuli take complete control, entirely redirecting and reprogramming the person's behaviour [20]. In other words, whatever the individual associates to the use of a substance becomes the sole priority in his/her mind, conditioning his/her behaviour dramatically.

ii. Apart from the single mechanism of action of each drug, all psychotropic substances also cause an increase in the dopamine levels released in the striatum [21,22] and the stronger and longer lasting learning signals associated to the abuse, increase the likelihood of that individual using the substance again. This effect reinforces itself and grows with each successive use of the substance, meaning that every new dose taken increases the probability of further use. iii. Altogether, the above-mentioned data show how the alterations in memory and learning processes of subjects afflicted by trauma and by severe substance addiction are very similar.

Trauma and drug-induced dissociation in the light of Complexity Theory

\section{The attractor}

Within Complexity Theory, of special relevance here is first and foremost the concept of the Attractor, which allows us to see how the patient's life functioning as a whole is compromised when drugs or trauma become part of it. It is very well known how both psychoactive substances and trauma can disrupt a person's existence, but our aim here is to point out how the substance - or rather the behaviour connected to the substance's use - and the trauma, can become an "Attractor" of this person's functioning, in the sense suggested by Complexity Theory.

It is also important to keep in mind that this disruption has more aspects to it:

i. It goes far beyond the actual psychotropic effect of the $\operatorname{drug}(\mathrm{s})$; in fact, simply quitting the substance does not eliminate the psychological effects of long-term abuse, as the latter are not limited to the use of the substance per se. Recovery from addiction and a life of sobriety do not guarantee, therefore, the full obliteration of the psychological experience connected to substance abuse.

ii. We can say the same thing for trauma, where the end of the traumatic event does not automatically delete the damage done to the personality. It can be so powerful as to completely transform an individual $[14,23]$.

iii. It is never entirely or simply a direct consequence of the subject's pre-morbid personality [24,25], or of any family and social variables in the individual's history.

iv. In a short amount of time a person becomes someone other than himself, just like Dr. Jekyll becomes Mr. Hyde ${ }^{4}$.

In other words, a gap opens between the past and present of the individual, especially in severe cases of abuse and trauma, and the addiction and the post-traumatic personality become the entire life of the individual and anything else becomes futile and dissociated. More

${ }^{2}$ Protein Kinase A (PKA) is a family of enzymes whose activity is dependent on cellular levels of cyclic AMP (cAMP). It acts to phosphorylate many enzymes important in metabolism and helps transfer the dopamine signal into cells. In the nucleus accumbens, which mediates reward, motivation, and task salience. The vast majority of reward perception involves neuronal activation in the nucleus accumbens, some examples of which include sex, recreational drugs, and food.

${ }^{3}$ CREB (cAMP response element-binding protein) is a cellular transcription factor. It binds to certain DNA sequences called cAMP response elements (CRE), thereby increasing or decreasing the transcription of the downstream genes. CREB has a well-documented role in neuronal plasticity and long-term memory formation in the brain.

${ }^{4}$ When Robert Louis Stevenson wrote his novel "The strange case of Dr. Jekyll and Mr. Hyde", he was probably thinking about some severe form of alcoholism. It is also interesting to note that he chose the term Juggernaut, to underline how Hyde was unstoppable: a century later, the same word was used for Marvel Comics's unstoppable monster, a man who, during his childhood, had been badly traumatized. 
specifically, the person's mind is affected by a kind of dissociation, which we regard as a clinical version of the Attractor [26].

\section{The Hypercycle and its Relation to the Historical Concept of Orpha}

We noticed that some of our patients, with severe cases of addiction or trauma, managed to develop the ability to "utilize" their own addiction or post-traumatic personality in a productive way; individuals with extraordinary skills and great adaptive capacity, who paradoxically maintained a certain psycho-physical stability for considerable lengths of time [27].

To better understand how this "sub-group" of patient's function, we shall now refer to a particular type of attractor, which is the hypercycle. A hypercyclic system generally functions by exponentially incrementing the speed at which it consumes and dissipates the resources necessary for its own growth - such as, for example, happens in the stage of exponential growth of a society largely reliant and dependent on petroleum oil as its energy supply. In the following pages, we shall explain how, in our view, within the field of psychoanalysis, psychoanalyst Sandor Ferenczi's concept of Orpha (1932) described the onset of a hypercyclic process in the mind of a traumatized subject.

Orpha is defined as a part of the individual's personality that rears its head when there is an inescapable trauma, much like a "guardian angel" or a primordial lifesaving force, allowing for the victim's psyche to run away from pain, to overcome fear and to somehow cope with the shock. What we are particularly interested in is the fact that once Orpha is awakened, it does not simply go away; in fact, it becomes the wisest and strongest part of the individual's personality. This fragment of personality, which Ferenczi names "orphic" (1932), may take up a huge role in the subject's psyche.

More specifically, and in the light of Complexity Theory, we could say that the orphic fragment of post-traumatic personality becomes the centre of a hyper-cyclic process so powerful that the individual's entire mind and life comes to revolve around it. That is why we maintain that the concept of Orpha, identified as the core of the hypercycle, can become a useful theoretical and clinical instrument in the treatment of severe forms of trauma and addiction [28].

As happens in some severe cases of addiction, once the hypercyclic process has been activated, the personality system is totally revolutionized, as the "Chemical Orpha" triggers a disproportionate growth of certain fragments of the personality, while all other areas become extremely dissociated, even at the expense of the most basic human needs such as affection, caring and intimacy.

The extent of the substance-induced dissociation is often such that the subject loses all trace of these aspects of the human condition and therefore no longer realises that he/she is lacking them. Such individual's personality is then characterized by profound voids, alongside remarkably "titanic" aspects, in an absolutely disharmonious juxtaposition $[29,30]$.

\section{Conclusion}

Through a review of the scientific research in these sectors, we found a broad overlap between the neurophysiological substrates of memory and learning mechanisms in subjects suffering from pathological dependencies and from severe trauma. Based on these data, and also supported by our own clinical practice observations, we suggest that the concepts of attractor and hypercycle, originating in Complexity Theory, provide a much-needed overarching interpretational framework for both substance-induced addiction and trauma, and represent very useful tools in making sense of and managing these two difficult clinical fields.

\section{Acknowledgement}

The authors thank Dr. Marco Raugei for his precious editing contributions. The authors also thank Cecilia Castellini for her competence in English language.

\section{References}

1. Zimmerman BJ, Labuhn AS (2012) Self-regulation of learning: Process approaches to personal development. In: KR Harris, S Graham, T Urdan (Eds.) APA Educational Psychology Handbook: Vol. 1. Theories, Constructs, and Critical Issues.

2. Schunk DH, Usher EL (2013) Barry J Zimmerman's theory of selfregulated learning. In: H. Bembenutty, TJ Cleary, Kitsantas A (Eds.) Applications of self-regulated learning across diverse disciplines: A tribute to Barry J. Zimmerman. Information Age Publishing, Charlotte, North Carolina, US State.

3. Linnenbrink EA, Pintrich PR (2003) The role of self-efficacy beliefs in student engagement and learning in the classroom. Reading \& Writing Quarterly 19: 119-137.

4. Beni F, Raugei M (2013) The Maximum (Em)Power Principle as a Cross-Disciplinary Interpretational Key: From Ecology to Psychology. In: Brown MT, S Sweeney, DE Campbell, S Huang, D Kang, et al. (eds). (2013) Emergy Synthesis 7: Theory and Applications of the Emergy Methodology. Proceedings of the 7th Biennial Emergy Conference. Center for Environmental Policy, University of Florida, Gainesville, US State 586 pages.

5. Beni F, Raugei M (2014) The Maximum (Em)Power Principle: A New Step in Bringing Psychoanalysis Closer to Modern Holistic Sciences. Dynamical Psychology 1.

6. Bandura A (1997) Self-efficacy: The exercise of control. Freeman, New York, USA.

7. Zimmerman BJ (2000) Self-efficacy: An essential motive to learn. Contemporary Educational Psychology 25: 82-91.

8. Pajares F (1996) Self-efficacy beliefs in achievement settings. Review of Educational Research 66: 543-578.

9. Schunk DH (1995) Self-efficacy and education and instruction. In J. E. Maddux (Ed.), Self-efficacy, adaptation, and adjustment: Theory, research, and application. Plenum Press, New York, USA, pp.281-303.

10. Cleary TJ, Platten P, Nelson A (2008) Effectiveness of the self-regulation empowerment program (SREP) with urban high school youth: An initial investigation. Journal of Advanced Academics 20: 70-107.

11. De Corte E, Mason L, Depaepe F, Verschaffel L (2011) Self-regulation of mathematical knowledge and skills. In: Zimmerman BJ, Schunk DH (Eds.), Handbook of self-regulation of learning and performance Routledge, New York, USA pp. 155-172. 
12. DiBenedetto MK, Zimmerman BJ (2010) Differences in self-regulatory processes among students studying science: A microanalytic investigation. The International Journal of Educational and Psychological Assessment 5: 2-24.

13. Usher EL, Pajares F (2006) Sources of academic and self-regulatory efficacy beliefs of entering middle school students. Contemporary Educational Psychology 31: 125-141.

14. Weiner B (1985) An attributional theory of achievement motivation and emotion. Psychological Review 92: 548-573.

15. Shell DF, Colvin C, Bruning RH (1995) Self-efficacy, attribution, and outcome expectancy mechanisms in reading and writing achievement: Grade-level and achievement-level differences. Journal of Educational Psychology 87: 386-398.

16. Bear GG, Minke KM, Griffin SM, Deemer SA (1998) Achievementrelated perceptions of children with learning disabilities and normal achievement: Group and developmental differences. Journal of Learning Disabilities 31: 91-104.

17. Borkowski JG, Carr M, Rellinger L, Pressley M (1990) Self-regulated cognition: Interdependence of metacognition, attributions and selfesteem. In: BJ Jones and L Idol (Eds.), Dimensions of thinking and cognitive instruction. Routledge, London, United Kingdom pp. 53-92.

18. Baird GL, Scott WD, Dearing E, Hamill SK (2009) Cognitive selfregulation in youth with and without learning disabilities: Academic self-efficacy, theories of intelligence, learning vs. performance goal preferences, and effort attributions. Journal of Social and Clinica Psychology 28: 881-908.

19. Stipek DJ (1993) Motivation to learn: From theory to practice ( $2^{\text {nd }}$ Edtn.) Allyn \& Bacon, Needham Heights, Massachusetts, United States.

20. Stipek DJ, Weiz JR (1981) Perceived personal control and academic achievement. Review of Educational Research 51: 101-137.

21. Zimmerman BJ, Martinez Pons M (1990) Student differences in selfregulated learning: Relating grade, sex, and giftedness to self-efficacy and strategy use. Journal of Educational Psychology 82: 51-59.
22. Tabassam W, Grainger J (2002) Self-concept, attributional style and self-efficacy beliefs of students with learning disabilities with and without attention deficit hyperactivity disorder. Learning Disability Quarterly 25: 141-151.

23. Nelson JM, Manset Williamson G (2006) The impact of explicit, self-regulatory reading comprehension strategy instruction on the reading-specific self-efficacy, attributions, and effect of students with reading disabilities. Learning Disability Quarterly 29: 213-230.

24. Berkeley S, Mastropieri MA, Scruggs TE (2011) Reading comprehension strategy instruction and attribution retraining for secondary students with learning and other mild disabilities. J Learn Disabil 44: 18-32.

25. Schunk DH, Cox PD (1986) Strategic training and attributional feedback with learning disabled students. Journal of Educational Psychology 78: 201-209.

26. Berkeley S, Larsen A, Colburn A, Yin R (2019) Self-regulation of middle school students with learning disabilities during a complex projectbased science activity. Journal of Educational and Developmental Psychology 9(2): 1-16.

27. Berkeley S, Mischel J, Whitehead A (2019) Self-regulation of students with learning disabilities during a complex, science-based project. Presentation at the Annual Meeting of the American Psychological Association, Chicago, USA.

28. Borkowski JG, Weyhing RS, Carr M (1988) Effects of attributional retraining on strategy-based reading comprehension in learning disabled students. Journal of Educational Psychology 80: 46-53.

29. Hiebert EJ, Winograd PN, Danner FW (1984) Children's attributions for failure and success in different aspects of reading. Journal of Educational Psychology 76: 1139-1148.

30. Morrone AS, Pintrich PR (2006) Achievement motivation. In: G Bear \& K Minke (Eds.), Children's Needs III: Development, prevention, and intervention. National Association of School Psychologists. Washington, USA

\section{Your next submission with Juniper Publishers will reach you the below assets}

- Quality Editorial service

- Swift Peer Review

- Reprints availability

- E-prints Service

- Manuscript Podcast for convenient understanding

- Global attainment for your research

- Manuscript accessibility in different formats ( Pdf, E-pub, Full Text, Audio)

- Unceasing customer service

Track the below URL for one-step submission https://juniperpublishers.com/online-submission.php 